\title{
Speed Reduction Mitigation Strategies on Rural Highways at Two-Way Stop Control Intersections and Curves
}

\author{
Ranjit Prasad Godavarthy'1, Eugene R. Russell², Babak Mirzazadeh1 \\ ${ }^{1}$ Upper Great Plains Transportation Institute, North Dakota State University, Fargo, ND, USA \\ ${ }^{2}$ Department of Civil Engineering, Kansas State University, Manhattan, KS, USA \\ Email:ranjit228@gmail.com,geno@ksu.edu,babak.mirzazadeh@ndsu.edu
}

How to cite this paper: Godavarthy, R.P., Russell, E.R. and Mirzazadeh, B. (2017) Speed Reduction Mitigation Strategies on Rural Highways at Two-Way Stop Control Intersections and Curves. Journal of Transportation Technologies, 7, 423-437. https://doi.org/10.4236/jtts.2017.74027

Received: September 16, 2017

Accepted: October 21, 2017

Published: October 24, 2017

Copyright $\odot 2017$ by authors and Scientific Research Publishing Inc. This work is licensed under the Creative Commons Attribution International License (CC BY 4.0).

http://creativecommons.org/licenses/by/4.0/

\begin{abstract}
Studies conducted on crashes at rural intersections of state highways and local roads/streets with two-way stop control have proved that the problem was likely poor judgment by the stopped driver on the minor approach of the speed of an oncoming vehicle and/or safe gap in traffic on the major highway. Several mitigating strategies have been suggested and studied in various studies to improve safety at the two-way stop control rural intersections and at other rural highway segments. There are also several low-cost techniques used, mostly in foreign countries, to slow drivers on major highways as they enter small towns and villages, e.g., narrowing pavement lines, establishing visual gateways, etc. Lowered speeds would decrease crash severity. In this study, four strategies including solar speed display units, mobile speed trailers, optical speed bars, and colored pavement were tested and assessed in some locations in Kansas. The results of this research indicate that both solar speed display units and mobile speed trailers are effective in speed reduction at the desired points, but optical speed bars and colored pavements do not yield reliable results. Additional studies and longer term studies, should be conducted.
\end{abstract}

\section{Keywords}

Rural Highway Safety, Rural Crashes, Speed Reduction Strategies, Two-Way Stop Control

\section{Background and Introduction}

The relationship between speed and safety is characterized by the physics of vehicle motion. Reduced speeds can likely yield safer driving because: 1) When 
traveling at a higher speed, a car moves a greater distance during the fixed period of time than that takes for the driver to react to a perceived problem. 2) The distance required to stop a vehicle by braking increases with speed. 3) Crash severity increases disproportionately with speed at impact. 4) On highways lacking adequate super elevation, a driver's ability to steer safely around curves diminishes with speed [1].

Rural roads are susceptible to a high rate of crashes, and the crash severities tend to be worse, leading to many fatalities and incapacitating-injury crashes [2] [3] [4] [5]. Solomon [6] studied the relationships between factors affecting the crash rates on major rural highways. The most relevant findings of the study are: 1) The greater the difference in the speed of a vehicle relative to the average roadway speed, the greater the chance of that vehicle being in an event. 2) Local drivers tended to have higher crash rates than other drivers. 3) Passenger cars with low horsepower had higher involvement rates in crashes, possibly due to low acceleration capability. 4) Nearly half of all crashes were either rear-end collision or same-direction sideswipes. 5) The proportion of angle collisions was highest at low speeds (less than $25 \mathrm{mph}$ ). 6) Drivers of older cars were more likely to be involved in a crash than drivers of newer vehicles [6].

Speed variation can be high in the case of vehicles on minor roads pulling out from an un-signalized cross road intersection and entering the traffic stream of a relatively high-speed major road. In a study for the Kansas Department of Transportation (KDOT) of rural state highway intersection crashes, it was suggested that one of the causes of crashes was drivers' inability to judge the speed and available gaps on the state highway [7]. One of the recommendations of that study was to find ways to slow vehicles on the state (major) highway, or to at least alert them to the intersection ahead and the possibility of vehicles entering the major roadway from a minor roadway [7].

Most of the conventional speed reduction techniques such as posted speeds (regulatory or warning) may not be effective sometimes to reduce the driver speed to a recommended level [8]. Further, other treatments such as flagging and police traffic control can be expensive and impossible to be implemented at all high-risk locations [8] [9]. Therefore, various techniques are adapted to reduce the speed at high-risk locations [8] [9] [10].

A NCHRP study was conducted to identify and evaluate treatments and develop guidelines to achieve speed reduction on high-speed approaches to intersection [11]. High-speed is defined as $45 \mathrm{mph}$ or greater in this study and the focus was primarily on physical treatments. The research team investigated a number of speed reduction treatments as a part of literature review which focused on geometric design, signing, and pavement marking techniques. Potential speed reduction treatments identified are reduced lane widths, visible shoulder treatments, speed tables, rumble strips, roadway environment, approach reserve curvature, roundabouts, splitter islands, wider longitudinal pavement markings, transverse pavement markings, and dynamic warning signs [11]. 


\section{Study Aim}

The aim of the study is to test reasonable number of speed mitigation strategies on the mainline at various intersections and highway segments selected by Kansas Department of Transportation. The intersections are with two way stop control treatment with stop signs on the minor road, and the mitigation strategies were designed to assist drivers in safely entering a state highway from a minor road stop sign; mitigation strategies were also tested for decreasing vehicle speeds in curve environments on rural highways.

\section{Study Objective and Methodology}

Literature review has identified a comprehensive list of appropriate countermeasures to slow drivers at specified points on approaches to various rural intersection and/or curve environments. The objective of the study is to determine suitable countermeasures to reduce speed on major roadways for two-way stop rural intersections and for curve environments. The final determination and selection of countermeasures to be tested was made by the project monitor in conjunction with other Kansas department of Transportation (KDOT) personnel. The final selection included two solar speed display units, two mobile speed trailers, optical speed bars on two curve locations and two sections of colored pavement; the locations were selected to as they were identified as potential locations with safety concerns.

KDOT was responsible for the installations and collection of the before and after speed data in accordance with their speed data collection policy, at locations selected by KDOT, and at the locations that the speed reduction was sought by KDOT. Data was collected at one point, the point where the speed reduction of the treatment was desired, as determined by the project monitor. Before and after speed data collection for four different treatment strategies at various locations were all carried out in year 2008; speed is measured using radar guns. Speed data where the solar speed displays and mobile speed trailers were used was taken at the intersection. The curves speed data was taken at the curve signs, which is very close to the beginning of the curves and the location where the optical bars started. The field technician always sits somewhere else in a location unobtrusive to the traveling public and aims the radar toward the same spot, trying to get 50 samples per direction of the traffic at the location in two hours. If they don't get the desired number in two hours they take whatever they have and leave after two hours. The data does not distinguish between cars and trucks in the speed studies for the purpose of this project but the numbers of each are known and can be determined if needed. Four treatments are selected for this study and their details are described in the below sub-sections.

\subsection{Solar Speed Display}

The solar speed displays used in this study were the type that shows the driver his/her speed (Figure 1). Description of the use of solar speed displays at the two 


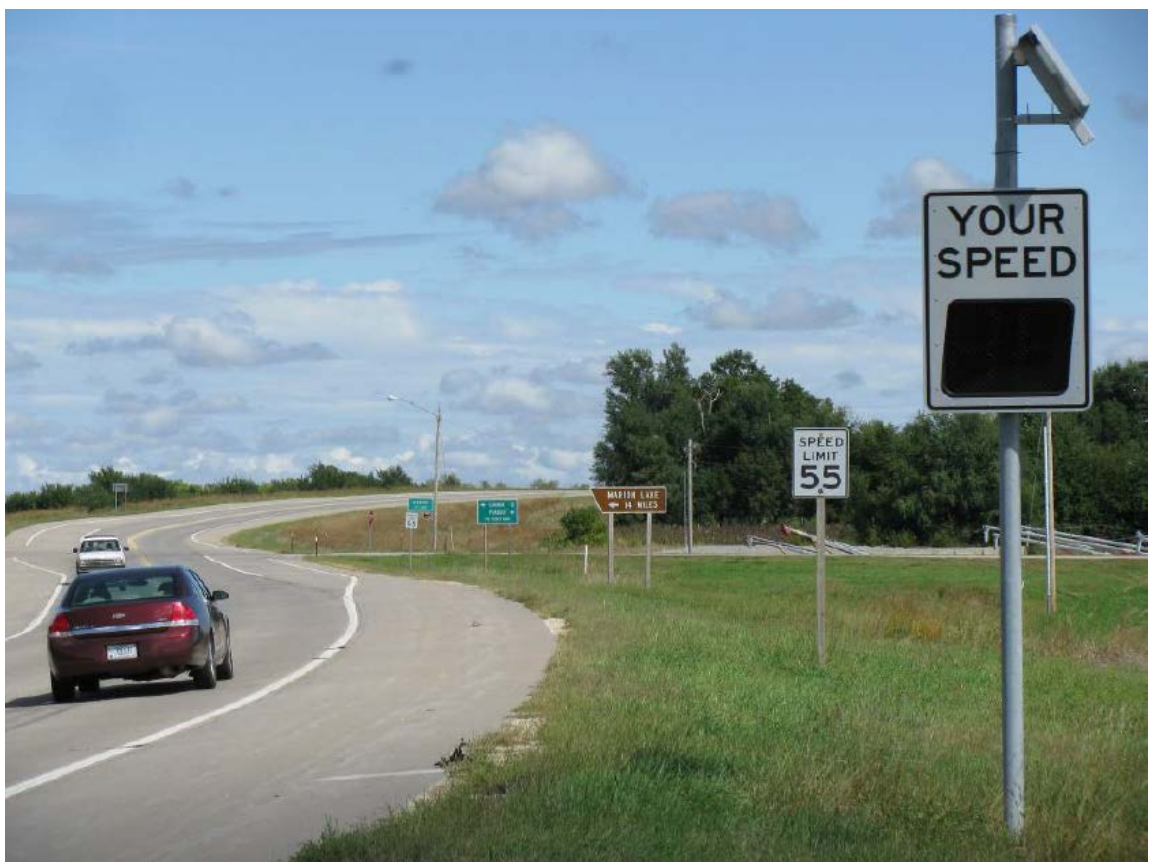

Figure 1. Solar speed display at west city limit, peabody (photo by Joe Palic).

locations selected by KDOT were summarized below:

- Cowley County, Winfield, Kansas, on US 77 at 33rd St, northbound lane. This is one of two locations where solar speed displays were placed. This location is just inside the city limits of Winfield on US-77. US-77 is 4 lane divided (painted median) posted at $55 \mathrm{MPH}$. 33rd St (also called Joel Mack Rd) is directly north of where the speed limit breaks from a rural $70 \mathrm{MPH}$ to an urban $55 \mathrm{MPH}$. The intersection of US-77 \& 33rd St has north and south bound left turn lanes, a southbound right turn lane and a northbound right turn taper. On 33rd St there is a stop sign on the east leg and a stop ahead and a stop sign on the west leg. US-77 has full asphalt shoulders (10 ft.) with edge line rumble strips in the area of 33rd St. There is city lighting in this area as well. The solar display unit was placed here, for northbound traffic only, due to the fact that it is difficult to get traffic to slow down to the 55 $\mathrm{MPH}$ by the time they are at 33rd St/Joel Mack Rd. The before and after data were taken at the intersection of 33rd St.

- Marion County, Peabody, Kansas, two locations on US 50, one at the West city limit facing eastbound traffic, the other at the east city limit facing westbound traffic. The second site for two Solar Speed Displays was on US-50 in Marion County, Peabody, KS. US-50 is a two lane undivided roadway, 10 foot shoulders with rumble strips. US 50 has a rural speed limit of $65 \mathrm{MPH}$. The speed limit drops to $55 \mathrm{MPH}$ at both the east city limit of Peabody east city limit and at the west city limit. A solar speed display was installed on US-50 at each city limit, facing west bound traffic at the east city limit and east bound traffic at the west city limit. Heading east on US-50 a driver would first encounter a reduced speed, "55 MPH ahead" sign about $850 \mathrm{ft}$. 
out from the posted $55 \mathrm{MPH}$ at the city limits. Just east (approx. $200 \mathrm{ft}$.) of "old Mill/Prairie Lawn", the driver will come across the city limit sign with a speed limit $55 \mathrm{MPH}$ sign attached. The eastbound solar display unit was installed after the reduced speed ahead sign but before the city limit/55 MPH sign (see Figure 1). The before data and after data were both taken at the east city limit of Peabody (Old Mill/Prairie Lawn Rd) - just inside the $55 \mathrm{MPH}$ urban speed zone for Peabody.

\subsection{Mobile Speed Trailer}

A mobile speed trailer was used at two locations, Pottawatomie, County, St. George, Kansas on US-24 at Flush Rd and in Sedgwick County, Goddard, Kansas, on 112 US-54 at 215th St. Description of the use of mobile speed trailers at the two locations selected by KDOT were summarized below:

- Pottawatomie County, St. George, Kansas, on US 24, facing westbound traffic at Flush Rd.: The US-24-Flush Rd intersection is between Manhattan and Wamego in rural Pottawatomie County. US-24 is a four lane divided highway posted at $70 \mathrm{MPH}$. At Flush Rd, US-24 has left and right turn lanes for both eastbound and westbound traffic. There are two crossroad signs (on the left and right side of the roadway) with flashing beacons for westbound traffic only. To the east of Flush Rd there is a slight vertical curve and hill, hence the crossroad signs with flashing beacons for westbound traffic. On Flush Rd there is a stop ahead signs and stop signs for both the northbound and southbound traffic. In the median KDOT has placed stop signs with flags for both northbound and southbound turning traffic. Before and after speed data was taken at the intersection of Flush Road.

- Sedgwick County, Goddard, Kansas, US 54 at 215 th St, facing eastbound traffic. The location of this mobile speed trailer is at US-54 \& 215 th St which can be described as west of Goddard. It is on a four-lane, divided highway posted at $70 \mathrm{MPH}$ with left turn lanes for both eastbound and westbound directions. The location has a stop ahead signs and a stop sign. No other signing or treatment has been done on US-54 or at 215th St. Before and after speed data was taken at the intersection of 215 th Street.

\subsection{Optical Speed Bars}

Optical speed bars are white transverse markings painted on both sides of the lane perpendicular to the centerline, edge line, or lane line in a pattern of progressively reduced spacing (Figure 2). This pattern gives drivers an impression of their speed being increased which can make the drivers to reduce their speeds. In this study, they are tested at two locations at curves to reduce speed. Optical speed bars in both locations start right at the curve signs. To lay them out the workers stood at the signs and made a line across the road and that's where the optical speed bars start. In the beginning of the section the bars are closer together. With increasing distance from the beginning of the curve the optical 


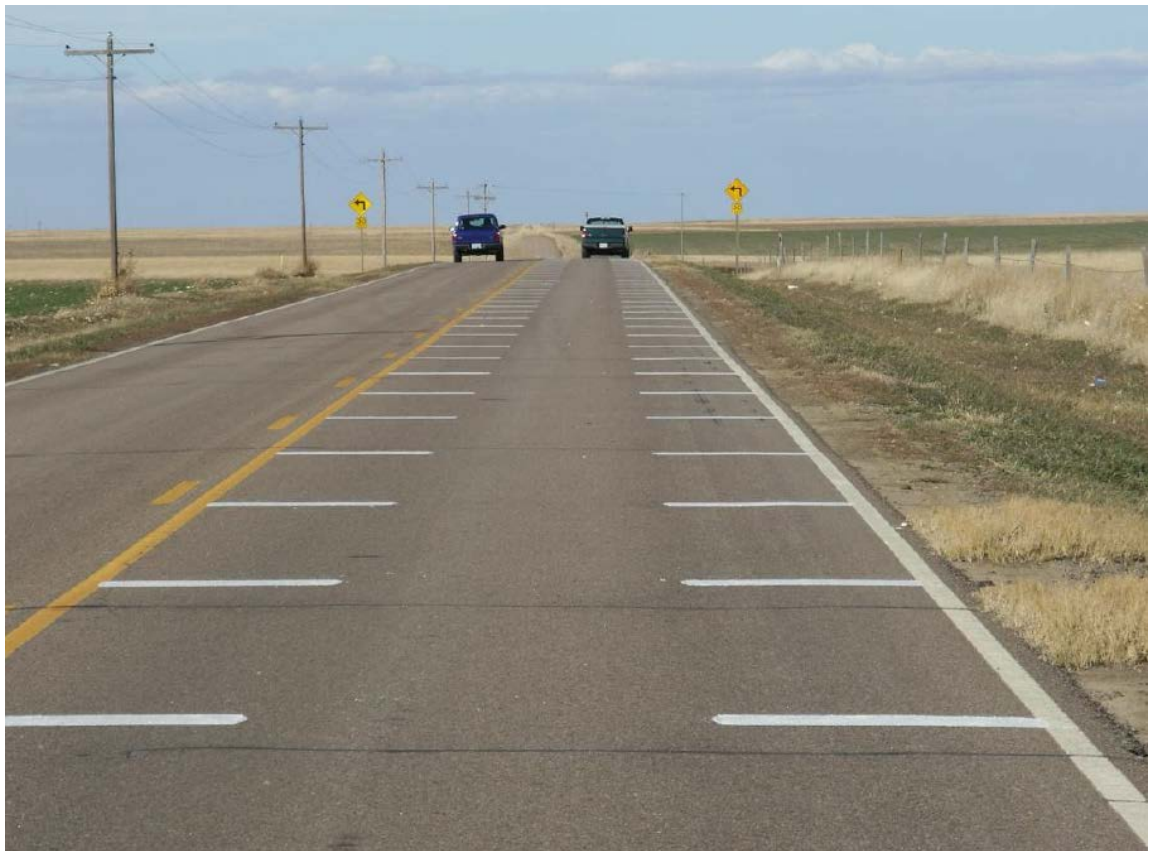

Figure 2. Picture of optical speed bars on K27 at approach to one of the curves.

speed bars get increasingly farther apart. The optical speed bars and curve signs can be considered at the beginning of the curves-where the roadway goes from relatively straight to curving. Description of the use of optical speed bars at the two locations selected by KDOT was summarized below:

- Wallace County, two locations on a $K-27$, one on the north curve approach, southbound lane; the other on the south curve approach, northbound lane: The two curves with the optical bars treatment are part of an "S" curve approximately 5 miles south of Sharon Springs on K-27 in Wallace County. For this study they were treated separately as the "North curve" and the "South curve". Curves signs with a speed advisory supplemental plate of $30 \mathrm{MPH}$ for each approach-two approaches for each curve, the north curve and the south curve, so there are a total of 4 curves signs with $30 \mathrm{MPH}$ speed advisory for each curve south and north. Each curve also has a large directional arrow sign to supplement the chevrons that are on each curve as well. The roadway is also stripped as "no passing" throughout the two curves. Between the two curves, K-27 does go in a straight alignment for a short distance. The distance from the beginning of the south curve to the end of the north curve is about 1 mile. The speed data for each curve was taken at the approach for each curve which would be the location of the curve signs. So for the "south" curve the data was taken as you enter the curve, going northbound, at the curve signs where the optical speed bars begin. At the curve signs are where it is desirable for drivers to slow down to $30 \mathrm{MPH}$ for the curves from the rural speed of 65 $\mathrm{MPH}$. For the "north" curve the data was taken at the first curve sign you would come to if you were traveling southbound on K-27. The optical speed bars at each curve were started at the curves signs and went out about 1200 
ft.- so the bars are closer together at the curve signs and spaced farther apart as you travel away from the curve to the south. The optical speed bars were meant to influence drivers to slow from $65 \mathrm{MPH}$ (rural speed) to $30 \mathrm{MPH}$ (at the curve signs). Nothing was done between the curves and no data was collected.

- Douglas County, US 24 curve near Midland Junction, at both east and west ends of curve, in westbound and eastbound lanes respectively. This location on US-24/US-59 near Midland Junction, an east-west highway, has two, 12 -foot asphalt lanes with three-foot paved shoulders. The speed limit is 55 $\mathrm{mph}$, reducing to $45 \mathrm{mph}$ thru one set of reverse curves. The curves are signed with a reverse curve warning sign and $45 \mathrm{mph}$ advisory speed plaque. There is also an intersection inside the curves signed with an intersection warning sign and $30 \mathrm{mph}$ advisory speed plaque. The optical bars were installed on each approach to the curve.

\subsection{Colored Pavement}

Colored pavement is constructed for a section of roadway for this strategy. Purple color pavement is selected for the two locations studied (Figure 3). The purple pavement installation is experimental; permission from FHWA was required and therefore obtained. The intent here is to bring speed of the vehicles travelling toward the city down from a rural speed limit. The purple pavement should emphasize the driving environment change from rural to urban. Purple was chosen because of the color relating to the school in the two locations studied. Description of the use of purple colored pavement sections at the two locations

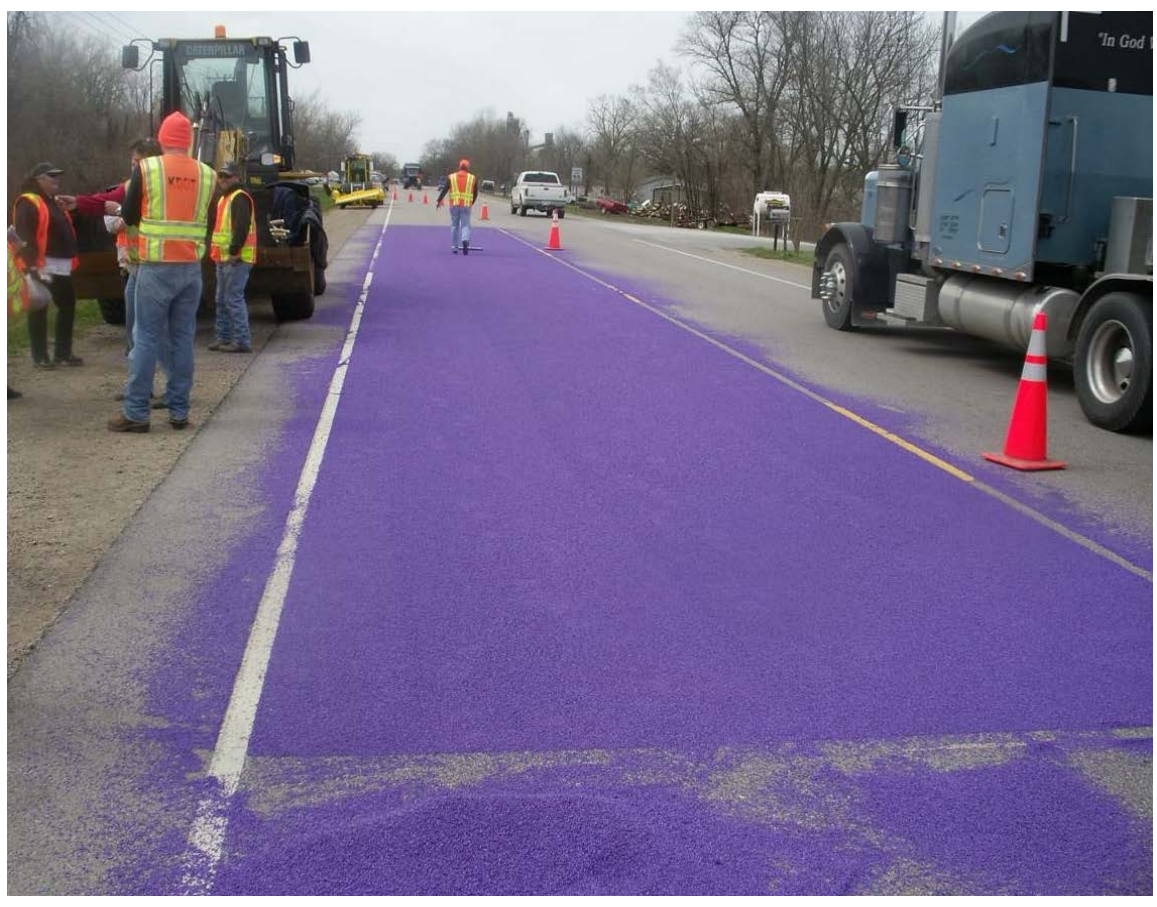

Figure 3. Picture of purple pavement on US59 at WCL of Atchison. 
selected by KDOT were summarized below:

- Atchison County near Atchison, Kansas, at the west city limit (WCL) on US 59, eastbound lane: The location of this section of colored pavement is on US 59 at the "new" WCL of Atchison, just west of the JCT US 59/US 73. US-59 is a 2 lane undivided roadway with 8 foot shoulders ( $2 \mathrm{ft}$. asphalt $/ 6 \mathrm{ft}$. turf), posted at $55 \mathrm{MPH}$. Other than the new, city limit sign, nothing is unusual about this location other than the purple tire-grip product that was installed. The purple pavement is in the US 59 eastbound (EB) lane. It extends from the city limit sign and goes for $100 \mathrm{ft}$. The lane is $12 \mathrm{ft}$. in width. The speed limit drops from $65 \mathrm{MPH}$ (rural) to $55 \mathrm{MPH}$ to the west of this location. The $55 \mathrm{MPH}$ acts as a transitional speed zone for this area as the speed limit goes from $55 \mathrm{MPH}$ to $45 \mathrm{MPH}$ east of the JCT US 59/US 73 where the "old" city limit sign was. The purple pavement is installed about in the middle of the 55 MPH transitional speed zone on US 59 at the "new" WCL of Atchison. Figure 3 below shows a picture of the colored pavement being installed, and Figure 4 below shows a close up of the tire-grip material.

- Clark County, Minneola, Kansas, two locations on US 283, one south of the south city limit, northbound lane; the other north of the north city limit, southbound lane: Clark County, Minneola, KS, on US 283, two sections of colored pavement were installed, 0.125 miles north and south of the north and south city limits of Minneola, respectively. The intent here is to bring speed of the vehicles travelling toward the city down from a rural speed limit of $65 \mathrm{MPH}$ gradually through a $55 \mathrm{MPH}$ zone, to a $30 \mathrm{MPH}$ zone ahead at the city limit. The purple pavement should emphasize the driving environment change from rural to urban and the $30 \mathrm{MPH}$ speed limit zone beginning at the city limits. Purple was chosen due to the high school's colors of purple/gold (yellow) and the installation at the south city limit is directly in front

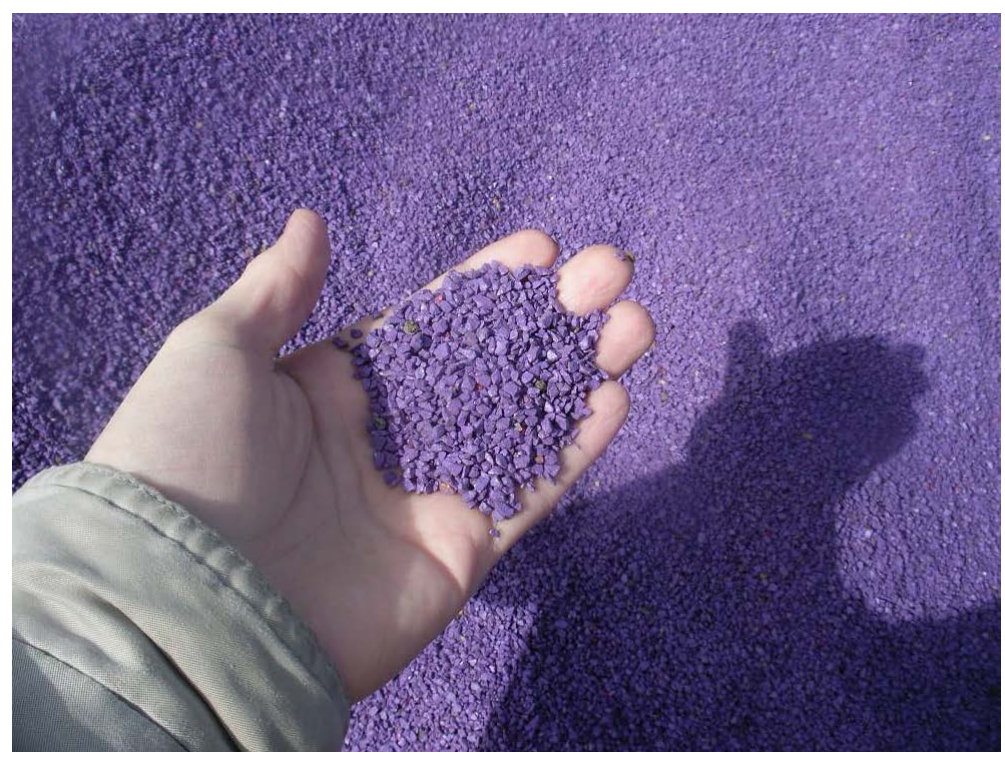

Figure 4. Close up of colored pavement tire-grip material. 
- of the high school. US-283 is a two lane undivided roadway with $3 \mathrm{ft}$. asphalt/turf shoulders, posted at a rural speed limit of $65 \mathrm{MPH}$. North of the north city limit there is a transitional speed zone of $55 \mathrm{MPH}$ that is 0.25 miles in length from the north city limit to 0.25 miles north of the north city limits. South of the south city limit is also a $55 \mathrm{MPH}$ transitional speed zone of 0.25 miles in length extending from the south city limit (SCL) to 0.25 miles south of the south city limit. At the city limits on US 283 the speed limit drops to 30 $\mathrm{MPH}$ at both the north city limit and south city limit of Minneola. The purple pavement was installed in the north bound (NB) US-283 lane (12 ft. width) beginning at the south city limit and went south for $100 \mathrm{ft}$. The north city limit installation was the same; it began at the north city limit sign and went north $100 \mathrm{ft}$. in the southbound US-283 lane. The data was taken approximately in the middle of the $55 \mathrm{MPH}$ speed zones. Each zone is 0.25 miles (1320 ft.) in length, so both before and after speed data were taken 0.125 miles ( $660 \mathrm{ft}$.) north of the north city limit and 0.125 miles south of the south city limit. The signing is exactly the same for the north approach (southbound US-283 going into Minneola) and the south approach (northbound US-283 going into Minneola). First the motorists would encounter a reduced speed ahead sign, a speed limit 55 sign, a reduced speed ahead sign then finally a city limit sign.

The research team was responsible for analyzing the before and after speed data for all the four treatments implemented and interpreting the results. A summary of the data and analysis of the before and after means speeds are shown below in Table 1; the before and after 85 th percentile speeds are shown in Table 2. For each location, KDOT provided a before and after set of the speeds of approximately 50 free flowing vehicles, taken at the point where speed reductions were desired. Based on a knowledge of statistics and the literature review of similar previous studies, it was decided that the key parameters for analysis would be the mean and 85th percentile speeds; and the t-test was the appropriate statistical test for determining if differences in the before and after mean and 85 th percentile were statistically significant. Statistical significance assures any difference in before and after speeds is due to the treatment of interest and not by chance.

In Table 1 and Table 2, the mean is the arithmetic average of the single before or after set of individual speeds provided, the 85 th percentile is the speed of each set that 85 percent of the individual vehicles are traveling at or below. A t-test is a commonly used, simple statistical procedure to determine if the difference between two samples (the before and after speed sets) is statistically significant. The t-test result at the 95 percent confidence level determined statistical significance. This value is the most common level used to analyze differences in data sets such as those used in this study. Statistical significance at this level means that chances are 95 out of 100 that there is a true difference in the before and after sets due to the treatment installed. 
Table 1. T-test of mean speed reduction for treatments studied.

\begin{tabular}{|c|c|c|c|c|c|c|}
\hline \multirow[b]{2}{*}{ County, City } & \multirow[b]{2}{*}{ Location } & \multirow[b]{2}{*}{ Treatment } & \multirow[b]{2}{*}{ Direction } & $\begin{array}{l}\text { Before } \\
\text { Study }\end{array}$ & $\begin{array}{l}\text { After } \\
\text { Study }\end{array}$ & \multirow{2}{*}{$\begin{array}{c}\text { Statistical } \\
\text { significance } \\
\text { of } t \text {-test for } \\
\text { mean speed } \\
\text { at } 95 \% \\
\text { confidence } \\
\text { interval }\end{array}$} \\
\hline & & & & $\begin{array}{c}\text { Mean } \\
\text { Speed, } \\
X 1 \\
(\mathrm{mph})\end{array}$ & $\begin{array}{c}\text { Mean } \\
\text { Speed, } \\
X 2 \\
(\mathrm{mph})\end{array}$ & \\
\hline Atchison & $\begin{array}{c}\text { US-59 @ } \\
\text { WCL }\end{array}$ & $\begin{array}{c}\text { Colored } \\
\text { Pavement }\end{array}$ & East & 51.1 & 50.7 & No \\
\hline \multirow{2}{*}{$\begin{array}{c}\text { Clark, } \\
\text { Minneola }\end{array}$} & $\begin{array}{l}\text { US-283, } \\
0.125 \\
\text { miles } \\
\text { South of } \\
\text { S.C.L }\end{array}$ & $\begin{array}{c}\text { Colored } \\
\text { Pavement }\end{array}$ & North & 48.8 & 42.4 & Yes \\
\hline & $\begin{array}{l}\text { US-283, } \\
0.125 \\
\text { miles } \\
\text { North of } \\
\text { N.C.L }\end{array}$ & $\begin{array}{l}\text { Colored } \\
\text { Pavement }\end{array}$ & South & 46.6 & 47.8 & $\begin{array}{l}\text { No (Speed } \\
\text { Increased) }\end{array}$ \\
\hline $\begin{array}{l}\text { Cowley, } \\
\text { Winfield }\end{array}$ & $\begin{array}{c}\text { US-77 @ } \\
\text { 33rd St }\end{array}$ & $\begin{array}{l}\text { Solar } \\
\text { Speed } \\
\text { Display }\end{array}$ & North & 53.2 & 51.5 & Yes \\
\hline \multirow{2}{*}{$\begin{array}{l}\text { Marion, } \\
\text { Peabody }\end{array}$} & $\begin{array}{c}\text { US-50 @ } \\
\text { W.C.L }\end{array}$ & $\begin{array}{c}\text { Solar } \\
\text { Speed } \\
\text { Display }\end{array}$ & East & 54.9 & 51.8 & Yes \\
\hline & $\begin{array}{c}\text { US-50 @ } \\
\text { E.C.L }\end{array}$ & $\begin{array}{l}\text { Solar } \\
\text { Speed } \\
\text { Display }\end{array}$ & West & 57.3 & 50.2 & Yes \\
\hline $\begin{array}{c}\text { Pottawatomie, } \\
\text { St. George }\end{array}$ & $\begin{array}{c}\text { US-24@ } \\
\text { Flush } \\
\text { Road }\end{array}$ & $\begin{array}{l}\text { Mobile } \\
\text { Speed } \\
\text { Trailer }\end{array}$ & West & 69.8 & 67.3 & Yes \\
\hline $\begin{array}{l}\text { Sedgwick, } \\
\text { Goddard }\end{array}$ & $\begin{array}{l}\text { US-54 \& } \\
215 \text { th St }\end{array}$ & $\begin{array}{l}\text { Mobile } \\
\text { Speed } \\
\text { Trailer }\end{array}$ & East & 62.4 & 55.3 & Yes \\
\hline Douglas & $\begin{array}{c}\text { US-24@ N } \\
2000 / \mathrm{E} \\
1400 \text { Strs. } \\
\text { Midland } \\
\text { Jct }\end{array}$ & $\begin{array}{c}\text { Optical } \\
\text { Speed Bars }\end{array}$ & East-West & 43.9 & 40.8 & Yes \\
\hline \multirow[b]{2}{*}{ Wallace } & $\begin{array}{c}\text { K-27, } \\
\text { North } \\
\text { curve } \\
\text { approach }\end{array}$ & $\begin{array}{c}\text { Optical } \\
\text { Speed Bars }\end{array}$ & $\begin{array}{l}\text { Combined } \\
\mathrm{NB} / \mathrm{SB}\end{array}$ & 47.8 & 52.9 & $\begin{array}{l}\text { No (Speed } \\
\text { Increased) }\end{array}$ \\
\hline & $\begin{array}{c}\text { K-27, } \\
\text { South } \\
\text { curve } \\
\text { approach }\end{array}$ & $\begin{array}{c}\text { Optical } \\
\text { Speed Bars }\end{array}$ & $\begin{array}{l}\text { Combined } \\
\mathrm{NB} / \mathrm{SB}\end{array}$ & 47.8 & 49.2 & No \\
\hline
\end{tabular}


Table 2. T-test of 85 th percentile speed reduction for treatments studied.

\begin{tabular}{|c|c|c|c|c|c|c|}
\hline & & & & $\begin{array}{l}\text { Before } \\
\text { Study }\end{array}$ & $\begin{array}{l}\text { After } \\
\text { Study }\end{array}$ & $\begin{array}{c}\text { Statistical } \\
\text { significance }\end{array}$ \\
\hline County, City & Location & Treatment & Direction & $\begin{array}{c}85 \text { th } \\
\text { Percentile } \\
\text { Speed, } X 1 \\
(\mathrm{mph})\end{array}$ & $\begin{array}{c}85 \text { th } \\
\text { Percentile } \\
\text { Speed, X2 } \\
(\mathrm{mph})\end{array}$ & $\begin{array}{c}85 \text { th } \\
\text { percentile } \\
\text { speed at } \\
95 \% \\
\text { confidence } \\
\text { interval }\end{array}$ \\
\hline Atchison & $\begin{array}{c}\text { US-59 @ } \\
\text { WCL }\end{array}$ & $\begin{array}{c}\text { Colored } \\
\text { Pavement }\end{array}$ & East & 54.8 & 55.3 & $\begin{array}{l}\text { No (Speed } \\
\text { Increased) }\end{array}$ \\
\hline Clark, & $\begin{array}{l}\text { US-283, } \\
0.125 \\
\text { miles } \\
\text { South of } \\
\text { S.C.L }\end{array}$ & $\begin{array}{l}\text { Colored } \\
\text { Pavement }\end{array}$ & North & 57.4 & 47.7 & Yes \\
\hline Minneola & $\begin{array}{c}\text { US-283, } \\
0.125 \\
\text { miles } \\
\text { North of } \\
\text { N.C.L }\end{array}$ & $\begin{array}{c}\text { Colored } \\
\text { Pavement }\end{array}$ & South & 51.8 & 52.9 & $\begin{array}{l}\text { No (Speed } \\
\text { Increased) }\end{array}$ \\
\hline $\begin{array}{l}\text { Cowley, } \\
\text { Winfield }\end{array}$ & $\begin{array}{c}\text { US-77 @ } \\
\text { 33rd St }\end{array}$ & $\begin{array}{c}\text { Solar } \\
\text { Speed } \\
\text { Display }\end{array}$ & North & 56.8 & 56.4 & No \\
\hline \multirow{2}{*}{$\begin{array}{l}\text { Marion, } \\
\text { Peabody }\end{array}$} & $\begin{array}{c}\text { US-50 @ } \\
\text { W.C.L }\end{array}$ & $\begin{array}{l}\text { Solar } \\
\text { Speed } \\
\text { Display }\end{array}$ & East & 58.5 & 56.3 & Yes \\
\hline & $\begin{array}{c}\text { US-50 @ } \\
\text { E.C.L }\end{array}$ & $\begin{array}{l}\text { Solar } \\
\text { Speed } \\
\text { Display }\end{array}$ & West & 63.2 & 54.1 & Yes \\
\hline $\begin{array}{c}\text { Pottawatomie, } \\
\text { St. George }\end{array}$ & $\begin{array}{c}\text { US-24@ } \\
\text { Flush } \\
\text { Road }\end{array}$ & $\begin{array}{l}\text { Mobile } \\
\text { Speed } \\
\text { Trailer }\end{array}$ & West & 73.2 & 71.1 & Yes \\
\hline $\begin{array}{l}\text { Sedgwick, } \\
\text { Goddard }\end{array}$ & $\begin{array}{l}\text { US-54 \& } \\
215 \text { th St }\end{array}$ & $\begin{array}{c}\text { Mobile } \\
\text { Speed } \\
\text { Trailer }\end{array}$ & East & 69.1 & 58.8 & Yes \\
\hline \multirow[b]{2}{*}{ Douglas } & US-24@ & & East & 45.2 & 45.2 & No \\
\hline & $\begin{array}{c}\text { N 2000/E } \\
1400 \\
\text { Strs. } \\
\text { Midland } \\
\text { Jct }\end{array}$ & $\begin{array}{l}\text { Optical } \\
\text { Speed } \\
\text { Bars }\end{array}$ & East-West & 46.8 & 45.9 & No \\
\hline \multirow{2}{*}{ Wallace } & $\begin{array}{l}\text { K-27, } \\
\text { North } \\
\text { curve } \\
\text { approach }\end{array}$ & $\begin{array}{l}\text { Optical } \\
\text { Speed } \\
\text { Bars }\end{array}$ & $\begin{array}{c}\text { Combined } \\
\mathrm{NB} / \mathrm{SB}\end{array}$ & 52.5 & 59.7 & $\begin{array}{l}\text { No (Speed } \\
\text { Increased) }\end{array}$ \\
\hline & $\begin{array}{l}\text { K-27, } \\
\text { South } \\
\text { curve } \\
\text { approach }\end{array}$ & $\begin{array}{l}\text { Optical } \\
\text { Speed } \\
\text { Bars }\end{array}$ & $\begin{array}{c}\text { Combined } \\
\mathrm{NB} / \mathrm{SB}\end{array}$ & 55.3 & 56.1 & $\begin{array}{l}\text { No (Speed } \\
\text { Increased) }\end{array}$ \\
\hline
\end{tabular}




\section{Discussion of Results}

\subsection{Solar Speed Displays}

1) Peabody. In Marion County, Peabody, Kansas the results were very promising. At the west city limit the result was a statistically significant decrease of 3.1 $\mathrm{mph}$ for eastbound vehicles. At the east city limit there was a statistically significant decrease of $7.1 \mathrm{mph}$, for westbound vehicles. The after mean speed decrease at the Peabody location indicates that the solar speed displays at these locations were very effective.

The 85th percentile before and after speeds also showed good results for the solar speed display at the two Peabody locations where they were installed. At the Peabody west city limit, eastbound traffic showed a decrease of $2.2 \mathrm{mph}$ which is statistically significant. At the Peabody east city limit, westbound decreases were $9.1 \mathrm{mph}$, also statistically significant.

2) Winfield: The after mean speed for northbound vehicles at the location south of Winfield showed a statistically significant decrease of $1.7 \mathrm{mph}$. At Winfield, the 85th percentile speed also showed a decrease of $2.4 \mathrm{mph}$ for northbound traffic. At Winfield positive results were not as pronounced in the histogram plot; however, the histogram plot of before and after speeds for the northbound traffic shows considerably more vehicles' speeds shifted to less than 52 $\mathrm{mph}$. Although the pace shifted only slightly to 48 to $57 \mathrm{mph}$ from 52 to $61 \mathrm{mph}$, the percent above pace decreased from $25.2 \%$ to $9.7 \%$ and the percent below pace increased from $9.7 \%$ to $25.2 \%$, indicating a greater percentage of drivers were driving at slower speeds.

\subsection{Mobile Speed Trailer}

1) Goddard: In Goddard, Kansas results appear to indicate that the mobile speed trailer at this location was exceptionally effective. Reductions in mean speed of $7.1 \mathrm{mph}$ for eastbound traffic are statistically significant and about twice the national average for speed trailers that can be found in the literature describing previous studies. The 85th percentile also shows statistically significant reductions at both locations; $10.3 \mathrm{mph}$ decrease for eastbound US-54 at Goddard.

2) St George, Flush Road: On US-24 at Flush Rd. near St. George, Kansas before and after mean speed results showed a $2.5 \mathrm{mph}$ decrease for westbound traffic. The westbound approach, because of combined curve and hill and southbound traffic on Flush Rd is a critical movement and the fact that there was a statistically significant decrease of the order found in other national studies, indicates that the device showed promise at this location. The 85 th percentile speeds at Flush road also show a statistically significant $2.1 \mathrm{mph}$ decrease for westbound US-24 traffic at Flush Road near St George.

\subsection{Optical Speed Bars}

Optical speed bars on curves were used at two locations. One was a curve in 
Douglas County on US-24 /US-59 near Midland Junction, both east and west approaches; the other in Wallace County on K-27at approaches to a "north" curve and a "south" curve. On US-24 in Douglas County there were reductions of $0.9 \mathrm{mph}, 3.1 \mathrm{mph}$ and $2.1 \mathrm{mph}$ for eastbound traffic, westbound traffic and combined eastbound westbound traffic, respectively, with the westbound and eastbound/westbound combined being statistically significant. These results show promise, particularly the $3.1 \mathrm{mph}$ reduction for the westbound traffic.

On K-27 in Wallace County, where optical speed bars were placed on approaches to an S-curve, treated as two separate curves, one referred to as the North curve and the other referred to as the South curve. The optical speed bars faced southbound traffic going into the north curve and northbound traffic going into the south curve. In each case the opposite direction traffic, northbound at the north curve and southbound at the south curve were going away from the curve and faced no optical speed bars nor any treatment. However, the data at the beginning of each curve data was combined with the opposite directions for both before and after traffic. Separated data is not available to the author. The combined after data for both North and South curves showed speed increases over the combined before data; however, no meaningful conclusions as to the effect of the optical speed bars at the K-27 location are possible at these curves.

Based on the results of the optical speed bars on the single curve on US-24 near Midland Junction, where westbound and westbound/eastbound combined showed statistically significant reductions of $3.1 \mathrm{mph}$ and $2.1 \mathrm{mph}$, respectively, indicate that additional studies of optical speed bars might prove them to be effective. Future studies should be conducted using a more rigorous data collection program. Also, the schedule for data collection shows that the optical speed bar installation was installed on November 12, 2008 and the after speed data was taken on November 19, 2008, seven days after installation. This time frame is too short for reliable long-term conclusions, as it may be too short for any novelty effects to wear off.

\subsection{Colored Pavement Sections}

1) Atchison: The mean speed results of the before and after mean speed on the colored pavement section on US-59 showed a $0.4 \mathrm{mph}$ decrease; however, the decrease was not statistically significant. A subjective observation from a histogram plot of combined before and after means speeds, indicates that the mean speed decrease was primarily due to a greater number of vehicles traveling at lower speeds, i.e. $50 \mathrm{mph}$ and a lower. The 85 th percentile after speed showed an increase of $0.5 \mathrm{mph}$ for eastbound traffic; however, the increase in the 85th percentile speed was not statistically significant. Based on the available data, there is no conclusive evidence that the colored pavement was effective for slowing vehicles at this location.

1) Minneola: On US-283 in Clark County, Minneola, Kansas, the mean speed 
data from 0.125 miles south of the South city limit showed a statistically significant drop of $6.4 \mathrm{mph}$ in northbound vehicles' speed, at the colored pavement section. However, for the section of US-283 north of the north city limit, the mean speed of southbound vehicles increased $1.2 \mathrm{mph}$, but these increases are not statistically significant. The 85th percentile speed on US-283 0.125 miles south of the south city limit also showed a statistically significant $9.7 \mathrm{mph}$ decrease in northbound vehicles' speed. However, in regard to the colored pavement 0.125 miles north of the north city limit, the data showed a $1.1 \mathrm{mph}$ increase for southbound vehicles' speed, but this increase was not statistically significant. The conclusion is that the colored pavement on US-283, Clark County was effective in slowing northbound vehicles at the location south of the south city limit but the data did not show it to be effective for slowing southbound vehicles at the location north of the north city limit.

\section{Conclusions}

In this study, the effectiveness of four treatments in slowing vehicles on highways was evaluated at either transition points to slower speeds, intersection approaches or curve approaches in rural areas. These treatments encompass colored pavement, solar speed display, mobile speed trailer, and optical speed bars. The solar speed displays and the mobile speed trailers were highly effective in reducing speeds on approaches to intersections and speed transition zones. The solar speed displays and the mobile speed trailers indicate statistically significant reductions in mean speed of from $1.70 \mathrm{mph}$ to $7.1 \mathrm{mph}$ and from $2.5 \mathrm{mph}$ to 7.1 $\mathrm{mph}$ respectively. Both the before and after data were based on a single set of data in a short period of time and no statistical inferences on the reliability of the actual magnitude of the reduction are possible. Nonetheless, when mobile speed trailers are used, short-term and immediate results are desired. In addition, based on the results of other studies including NCHRP Report 613 [4], it is concluded that these treatments show appropriate potential for speed reduction and should be effective in a variety of highway environments. Optical speed bars did not show statistically significant results. In Douglas county, only the westbound and combined eastbound-westbound bars exhibited statistically significant reduction in the mean speed. Similar to the optical speed bars, the sections of colored pavement did not yield reliable results. Only on US-283 at the south city limit of Minneola, there was statistically significant decrease of $6.4 \mathrm{mph}$ in the mean speed and $9.7 \mathrm{mph}$ in the 85th percentile speed and hence, it cannot be concluded that the colored pavement sections were effective in reducing speeds.

Based on the results of this study, it can be concluded that both the solar speed display units and mobile speed trailers used on this study were effective in reducing speeds at the desired points. In regard to the colored pavement sections and the optical speed bars, it cannot be concluded that they were effective; however, some mixed results of the optical speed bar data analysis on US-24 in Douglas County near Midland Junction indicated that there is the possibility 
that they could be effective.

\section{Acknowledgements}

The funding for this study is provided by Kansas Department of Transportation.

\section{References}

[1] Transportation Research Board (1984) A Decade of Experience, Special Report 204, Transportation Research Board, Washington DC.

[2] Dissanayake, S. and Perera, L. (2011) A Survey Based Study of Factors Related to Older Driver Highway Safety. Journal of Transportation Safety \& Security, 3, 77-94. https://doi.org/10.1080/19439962.2010.537437

[3] Perera, L. and Dissanayake, S. (2010) Contributing Factors to Older-Driver Injury Severity in Rural and Urban Areas. Journal of Transportation Research Forum, 49, $5-22$.

[4] Perera, L. and Dissanayake, S. (2009) Survey-Based Approach to Identify Highway Safety Characteristics and Issues of Older Drivers. Proceedings of the 2009 Mid-Continent Transportation Research Symposium, Ames, Iowa.

[5] Perera, H.L.K. (2009) An Analysis of Older-Driver Involvement in Crashes and Injury Severity in Kansas. Kansas State University, Kansas, USA.

[6] Solomon, D. (1974) Accidents on Main Rural Highways Related to Speed, Driver, and Vehicle. U.S. Department of Transportation, Federal Highway Administration, Washington DC.

[7] Stokes, R.W., Rys, M., Russell, E.R., Robinson, R.K. and Budke, B. (2000) Analysis of Rural Intersection Accidents Caused by Stop Sign Violation and Failure to Yield the Right-of-Way. Report No. K-TRAN KSU-98-6, Kansas Department of Transportation.

[8] Katz, B.J. (2004) Pavement Markings for Speed Reduction. Traffic Control Devices Pooled Fund Study, TPF-5(065).

[9] Russell, E.R. and Godavarthy, R.P. (2010) Mitigating Crashes at High-Risk Rural Intersections with Two-Way Stop Control. Report No. K-TRAN: KSU-06-4, Kansas Department of Transportation.

[10] Godavarthy, R.P. and Russell, E.R. (2016) High-Risk Rural Road Safety Study and Determining the Crash-Reduction Factors for High-Risk Rural-Road Usage. Journal of Transportation Technologies, 6, 1-8. https://doi.org/10.4236/jtts.2016.61001

[11] Ray, B., Kittelson, W., Knudsen, J., Nevers, B., Ryus, P. and Sylverster, K. (2008) Guidelines for Selection of Speed Reduction Treatments at High-Speed Intersections. NCHRP Report 613, Transportation Research Board, Washington DC. 